\title{
Benign Paroxysmal Vertigo, and Bárány's Caloric Reactions
}

\author{
J.M.S. Pearce \\ Emeritus Consultant Neurologist, Department of Neurology, Hull Royal Infirmary, Hull, UK
}

\section{Key Words}

Benign positional vertigo • Bárány · Caloric reactions

\begin{abstract}
The Nobel Prize winner Robert Bárány described benign positional vertigo and related it to the otoliths in 1921. Dix and Hallpike further elucidated this clinically distinctive, common disorder in 1952. The displacement of otoliths from the utricle or saccule into one of the semicircular canals later proved to be the underlying mechanism, described by Schuknecht and utilised therapeutically by Semont and Epley.

Copyright $\odot 2007$ S. Karger AG, Basel
\end{abstract}

The first description of benign paroxysmal vertigo (BPV) is attributed to Adler [1] in 1897. Robert Bárány, who was awarded in 1914 the Nobel Lecture entitled 'Some new methods for functional testing of the vestibular apparatus and the cerebellum', initiated caloric testing. In 1921, Bárány [2] described episodic vertigo, induced when the subject suddenly moved his/her head; the vertigo was abrupt in onset and lasted a few seconds. He related it to a disorder of the otoliths. The vertigo is much briefer than that of labyrinthitis, vestibular neuronitis [3] and Menière's syndrome. Dix and Hallpike [4] in 1952 gave a more detailed account, indicated the good prognosis and named the syndrome 'benign paroxysmal positional vertigo' [5]. Using a positional test they showed that the undermost ear caused the characteristic rotational nystagmus. The Dix-Hallpike test is performed with the patient

\section{KARGER}

Fax +4161306 1234

E-Mail karger@karger.ch

www.karger.com
(C) 2007 S. Karger AG, Basel

0014-3022/07/0574-0246\$23.50/0

Accessible online at:

www.karger.com/ene in the supine position with the head hanging over the edge of the examining couch, a rapid turn of the head, $30^{\circ}$ to the left, right or centre, after a few seconds causes intense vertigo with visible positional nystagmus lasting less than $1 \mathrm{~min}$, which fatigues on repeated manoeuvres in the critical position. The latency of vertigo and nystagmus ranges from 1 to $20 \mathrm{~s}$. It usually subsides within $30-60 \mathrm{~s}$ and fatigues with repeated positioning. Vertigo coincides with the nystagmus. Clinical investigation suggests a peripheral, posterior semicircular canal origin [6]. Using the Hallpike test, BPV is readily diagnosed. Women are affected slightly more often $(3: 2)$ than men. The incidence is about 64 per 100,000 population per year.

\section{Pathophysiology}

In the 19th century, Magnus Gustaf Retzius (18421919), Swedish anatomist and anthropologist, best known for his studies of neural histology, had established the anatomy of the ear and semicircular canals. The physiologist Jean Pierre Flourens (1794-1867) in 1825 had observed that when a pigeon's horizontal semicircular canal was destroyed, it went on turning horizontally in a circle. Jan Evangelista Purkinje (1787-1869) proved that changing head position induced vertigo in man. But because no experiments on rotating the head in animals were performed, Bárány [2] somewhat abrasively remarked:

'Science stood still in this respect for nearly 40 years.'

In 1861, Prosper Ménière (1799-1862) had related vertigo and tinnitus to inner ear disease. However, the im-

J.M.S. Pearce

304 Beverley Road

Anlaby, East Yorks HU10 7BG (UK) 
portant deduction that if the destruction of the semicircular canal apparatus caused vertigo and imbalance, then the normal function of this apparatus must be to maintain equilibrium, was made by Goltz in 1870 .

Bárány's 1916 Nobel Lecture recounts his discovery of the caloric reaction, which if positive, showed the canals were excitable, if negative then they were - with few exceptions - destroyed.

\section{History of the Caloric Vestibular Reactions}

Bárány discovered the caloric reactions of the labyrinths when he noticed that syringing the ears produced nystagmus and giddiness:

'Chance came to my aid. One of my patients, whose ears I was syringing, said to me: "Doctor, I only get giddy when the water is not warm enough. When I do my own ears at home and use warm enough water I never get giddy." I then called the nurse and asked her to get me warmer water for the syringe. She maintained that it was already warm enough. I replied that if the patient found it too cold we should conform to his wish. The next time she brought me very hot water in the bowl. When I syringed the patient's ear he shouted: "But Doctor, this water is much too hot and now I am giddy again." I quickly observed his eyes and noticed that the nystagmus was in an exactly opposite direction from the previous one when cold water had been used. It came to me then in a flash that obviously the temperature of the water was responsible for the nystagmus. From this I immediately drew certain conclusions. If the temperature of the water was really responsible, then water at exactly body temperature should cause neither nystagmus nor vertigo. An experiment confirmed this conclusion. Furthermore, I said to myself, if it is the temperature of the water, nystagmus must be caused in normal cases also and not only in cases of suppurating ears. This I was also able to prove' [7].

The caloric reaction originated in the semicircular canals in which the specific gravity of endolymph increases with cooling tends to sink, whereas with warming the specific gravity decreases and the fluid tends to rise. The caloric reaction established a method of investigation of the excitability of the vestibular apparatus. If the reaction was positive, the canals were excitable, i.e. not totally destroyed, if it was negative, then they were destroyed - with a few exceptions [7].

The mechanism of BPV started to unravel in 1962, when Schuknecht [8] suggested that degenerative material (otoliths) dislodged from the utricle became attached to the cupula of the posterior semicircular canal: cupulolithiasis. The otoliths are normally attached to hair cells of the utricle and saccule. Because they are denser than the surrounding endolymph, vertical head movement causes the otoliths to tilt the hair cells. The otoliths may become displaced from the utricle by aging, head injury, or stapes surgery or infective labyrinthitis, into the semicircular canals; but mostly the cause is unknown. They usually enter the posterior, most dependent semicircular canal. This mechanism is supported by the presence at surgery of granular basophilic deposits on the cupulae of the posterior semicircular canals in BPV patients.

The alternative canalolithiasis theory predicates that otoliths are free floating within the canal. When the head position changes, the endolymph moves with the otoliths, which stimulate the hair cells of the cupola of the affected semicircular canal, causing vertigo. When the otoliths stop moving, the endolymph also stops and the hair cells return to their baseline position, thus terminating the vertigo and nystagmus. When the head manoeuvre is reversed, the particles move in the opposite direction. In this theory, repeating the head manoeuvres gradually disperses the otoliths, causing diminishing vertigo and nystagmus, i.e. fatigability. Thus, canalith repositioning was attempted as treatment by the Semont manoeuvre, the rapid and vigorous side-to-side head and body movements. Similarly, Epley's manoeuvre $[9,10]$ sequentially moves the head in 4 different positions; for each the rate is titrated to the point of no nystagmus and no symptoms - usually about $30 \mathrm{~s}$. Benefit occurs [11] in a few days in about $70-90 \%$ of patients. However, the efficacy of the positioning manoeuvres in benign positional vertigo has been questioned [12], since spontaneous remission within $4-12$ weeks is the rule, with late recurrence in about $10 \%$ of subjects.

\section{Robert Bárány}

Robert Bárány was born on April 22, 1876, in Vienna [7] (fig. 1). He excelled at school, stimulated mainly by a clever mother, Maria Hock, daughter of a Prague scientist. He studied medicine at Vienna, graduating in 1900 [13]. Bárány attended Professor C. von Noorden in Frankfurt am Main for 1 year and then studied at Kraepelin's ${ }^{1}$ clinic in Freiburg, where his interest in neurology was aroused. He returned to Vienna and in 1903 became demonstrator at the Otological Clinic under Politzer (1835-1920), founder of Austrian otology. He followed up the experimental work of Flourens, Purkinje, Mach, Breuer and others, and clarified the physiology and pathology of the human vestibular apparatus $[2,14]$.

\footnotetext{
1 Spelled Kracpelin [sic] in Nobel Lecture and elsewhere.
} 
Fig. 1. Austrian stamp of Dr. Robert Bárány.

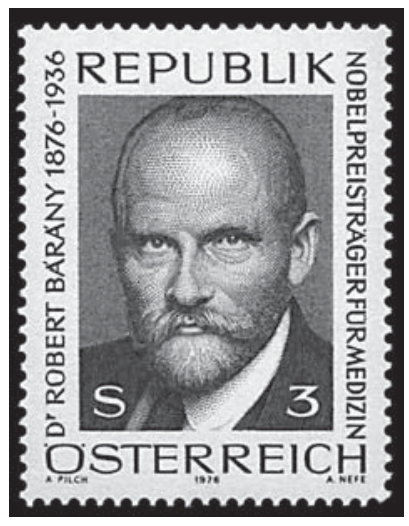

As a civilian surgeon he joined the Austrian army tending soldiers with head injuries. He continued to work on the correlation of the vestibular apparatus, the cerebellum and the muscular apparatus, establishing the vestibular reactions to movement, and Bárány's pointing test. His work [2] greatly expanded the physiology and pathology of the human vestibular apparatus. In 1914 he was awarded the Nobel Prize but was at the time incarcer- ated in a prisoner of war camp. After the intervention of Prince Carl of Sweden he was released in 1916 and was presented with the Nobel Prize by the King of Sweden at Stockholm (Nobel Lecture 1916, entitled 'Some new methods for functional testing of the vestibular apparatus and the cerebellum'). After the Nobel Prize, Bárány received accusations from colleagues that he failed to acknowledge his collaborators' contributions. He never returned to Vienna. However, Bárány moved to the post of Principal of the Otological Institutet in Uppsala. Holmgren and several famous Swedish otologists published a paper in defence of Bárány and most of the charges proved false. As head of the Otological Clinic Bárány's school expanded its reputation and attracted students from afar.

Robert Bárány married Ida Felicitas Berger in 1909. They had a daughter and 2 sons: the elder a professor of pharmacology, his brother assistant professor of medicine at the Karolinska Institutet. Later in life Robert studied rheumatism and continued working on a book on this topic after suffering a disabling stroke. He died at Uppsala on April 8, 1936.

\section{References}

1 Katsarkas A: Paroxysmal positional vertigo: an overview. Am J Otol 1995;16:725-730.

2 Bárány R: Diagnose von Krankheitserscheinungen im Bereiche des Otolithenapparatus. Acta Otolaryngol (Stockholm) 1921;2:434437.

-3 Dix MR, Hallpike CS, Hood JD: The investigation of vestibular function. Br Med Bull 1956;12:131-142.

4 Dix M, Hallpike CS: Pathology, symptomatology and diagnosis of certain disorders of the vestibular system. Proc R Soc Med 1952; 45:341-354.

5 Dix R, Hallpike CS: The pathology, symptomatology and diagnosis of certain common disorders of the vestibular system. Ann Otol Rhinol Laryngol 1952;61:987-1016.
6 6 Baloh RW, Honrubia V, Jacobson K: Benign positional vertigo: clinical and oculographic features in 240 cases. Neurology 1987;37: 371-378.

7 Bárány R: Some new methods for functional testing of the vestibular apparatus and the cerebellum (Nobel Lecture, September 11, 1916); in: Nobel Lectures, Physiology or Medicine 1901-1921. Amsterdam, Elsevier Publishing Company, 1967.

8 Schuknecht HF: Positional vertigo: clinical and experimental observations. Trans Am Acad Ophthalmol Otolaryngol 1962;66:319332.

$\checkmark 9$ Epley JM: The canalith repositioning procedure: for treatment of benign paroxysmal positional vertigo. Otolaryngol Head Neck Surg 1992;107:399-404.
10 Li JC, Epley J: The 360-degree maneuver for treatment of benign positional vertigo. Otol Neurotol 2006;27:71-77.

-11 Hilton M, Pinder D: The Epley manoeuvre for benign paroxysmal positional vertigo - A systematic review. Clin Otolaryngol Allied Sci 2002;27:440-445.

12 Katsarkas A: Paroxysmal positional vertigo: an overview and the deposits repositioning maneuver. Am J Otol 1995; 16:725-730.

13 Nylen CO: Robert Bárány. Arch Otolaryngol 1965;82:316.

14 Bárány R: Untersuchungen über den vom Vestibularapparat des Ohres reflektorisch ausgelösten rhythmischen Nystagmus und seine Begleiterscheinungen: ein Beitrag zur Physiologie und Pathologie des Bogengangapparates. Monatsschr Ohrenheilkd 1907; 41:477-526. 